\title{
Beyond Gone With the Wind; the Contribution of La Bicyclette bleue
}

Moishe Black

University of Saskatchewan

$I_{1}$

In Lyons, in 1985, my wife suddenly stopped talking to me, so absorbed was she in reading the first two volumes of a novel called La Bicyclette bleue. She broke the silence to utter a cry of distress the day a bookseller told her that volume three was not yet in print.

From a newspaper article, I subsequently discovered that the whole of France had been breathlessly awaiting part three of Régine Deforges' novel: «Tout le monde, ou presque, a lu La Bicyclette bleue,» wrote Dimanche Magazine (see list of sources), referring to volumes one and two. Unlike tout le monde, however, we were going home to Canada in July, and great was the tension in our household: would part three appear before we left? It did. ${ }^{1}$

I in turn read the trilogy and found it very absorbing. More, I thought it good literature, but had difficulty verbalizing my admiration because Deforges' opus reminded me strongly of Gone With the Wind. Overcoming that difficulty in order to arrive at an assessment of La Bicyclette bleue is my topic here.

Since I had read Margaret Mitchell's book once, thirty years earlier, and seen the film once, ${ }^{2}$ anyone not familiar with both novels may infer how strong must be the resemblance. Consider merely the first chapter of each. Gone With the Wind opens on a big cotton plantation in the southern United States; the imminence of war between the states is on everyone's lips, or nearly everyone's. La Bicyclette bleue opens on a big wine-growing estate in southern France; the impending war with Hitler's Germany is on everbody's mind, or almost everybody's.

The exception in Mitchell's novel is a spoiled, flirtatious, strikingly attractive girl named Scarlett. Scarlett is first in a rotten frame of mind because even her faithful admirers the Tarleton twins are discussing the stupid war; and then shocked when the twins tell her that Ashley, the man she thinks she loves, is about to marry someone else: the nauseatingly good Melanie. The odd person out in Deforges' book is a self-centred, bantering, vital creature called Léa. Léa starts off by displaying ill temper because even her usual worshipers, the Lefèvre twins, are talking about the wretched war; and then she is stunned when the duo reveal that her girlhood dream-man, Laurent, is going to wed another: the mawkishly sweet Camille.

Subsequently each of the heroines throws herself at the discomfited bridegroom in the privacy of a library/a conservatory, and love turns to fury as each woman is scorned. A swarthy, cynical stranger named Rhett Butler, napping unseen in the 
library, mocks Scarlett's anger; a dark, blunt-spoken outsider called François Tavernier, resting unnoticed in the conservatory, sneers at Léa's.

For 'the burning of Atlanta,' read 'the bombardment of Orléans.' And so forth and so on, at any rate well into volume one of La Bicyclette bleue. A congruity of text which is enhanced by congruity of external circumstance: each novel was written by a woman and each became what could be called an absolute bestseller in its home country - up to 1989, 26 million copies for Gone With the Wind, 61/2 million for La Bicyclette bleue (Taylor, p. 1 and newspaper Libération, 7 (déc. 1989), 36). ${ }^{3}$

A further distracting element, for the reader initially interested, as I was, in the French novel rather than the American one, is that the borrowings described above have never been denied. The Dictionnaire des littératures de langue française (vol. A-D, 645) reports as common knowledge that Deforges' book started off to be a commissioned work, «une commande," with a "modèle imposé (Autant en emporte le vent).» Le Monde (5 oct. 1989, 17) is likewise unequivocal: publisher Jean-Pierre Ramsay and his author «avaient à l'époque clairement annoncé leur intention de jouer avec le bouquin de la dame Mitchell,» simply because Ramsay, says the newspaper, «cherchait des sujets pour ses auteurs.»

There are even 'acknowledgments' between the covers of Deforges' book. At the end of volume three, one finds appended the statement: "L'auteur tient à remercier pour leur collaboration, la plus souvent involontaire, les personnes suivantes," followed by a long list of names, including Winston Churchill and Margaret Mitchell. And on page 172 of that volume, heroine Léa Delmas stretches out on her bed to read a novel recommended by her sister, a novel about people called Scarlett and Rhett from which there is a substantial quotation in French! Far from being covert, the whole matter of imitation is treated as a good joke.

It was not taken in that spirit by those responsible for the rights to Gone With the Wind, especially after the appearance of a translation called The Blue Bicycle ${ }^{4}$ had made Deforges' novel accessible to the American public. There began a legal dispute which continues as of the present writing (spring 1992); this dispute further points up the critic's problem of too much similarity, and also offers the germ of a solution.

I first learned of the judicial struggle via the press. Acting for two of Margaret Mitchell's heirs, Trust Company Bank of Atlanta took the matter to a French courtroom, where in 1989 Deforges failed what Libération (4 oct., 37) referred to as her «épreuve de littérature comparée.» Her lawyers pleaded that the unauthorized remake had never materialized. After a mere 75 of the trilogy's 1,200 pages, they argued, Deforges had veered off in another direction to produce an entirely different novel. The resemblances were thus reduced to a long-established and respectable literary device, which consists of evoking a well-known work in order to lead the reader to a new work.

Vain arguments! The French court ruled that La Bicyclette bleue was a «reproduction illicite» of Gone With the Wind, full of «emprunts parfaitement localisables [qui] portent sur tous les éléments constitutifs intrinsèques de l'oeuvre» (words of the court, 
in Libé. 7 déc. 1989, 36). Ramsay Publishers, now owned by Deforges, were ordered to pay two million francs in damages and stop publishing the book.

The court bolstered its ruling with 94 pages of side by side resemblances covering «l'intrigue romanesque générale, le plan du récit, ... les caractéristiques physiques et psychologiques des principaux personnages, ... les ressorts dramatiques, [etc.]» (court, in Libération 7 (déc. 1989, 36). There was no solace for me as critic, in this direct factual approach; on the contrary it gave substance to my problem.

Further enquiry, however, led me to consult reports of proceedings and to discover that there had been an earlier legal action leading to a different result. Trust Company Bank, and MacMillan (holder of publishing rights to Gone With the Wind), had first tried to negotiate, and when that failed had applied to a California district court with a complaint against one French and three American publishers. They alleged that The Blue Bicycle, in this context meaning volume one of the trilogy, constituted an infringement of copyright.

In giving its decision, the California court explained the method it had followed. The court had applied a 'balancing test,' sometimes used in such cases, and which involves the concept of 'substantial similarity'. To show substantial similarity requires two separate analyses. "First, there must be substantial similarity as to the works' general ideas (the 'extrinsic' test); second, there must be substantial similarity as to their underlying protectible expression (the 'intrinsic' test ...)." For the intrinsic test, "the Court must determine whether the defendant's work has reproduced 'the total concept and feel' of the plaintiff's work."

Applying this method, the court found that "although there are similarities in scenes and the sequence of events of the two works, the expression of the scenes in The Blue Bicycle and Gone With The Wind differ [sic]. Therefore, the Court concludes that the 'total concept and feel' of the two works is not substantially similar." The application was dismissed (see sources, Printout). ${ }^{6}$

Aside from the admirable examples of disinterested justice -a United States judge finding for a French defendant, a French one for a plaintiff from the U.S.A. - there was much food for thought in the evaluative approach just described: 'extrinsic test,' 'intrinsic test,' 'total concept and feel;' and, in an unrelated court case opposing Gone With the Wind to an operetta called Scarlett Fever, references to a 'functional test' (what does each work set out to do?) as well as a 'recall or conjure up' test (does one work fundamentally evoke the other?) (Federal Supplement, 354-363). American law, it appears, has developed sophisticated instruments for comparing creative works. I took heart from this idea that external similarities can conceal deeper conceptual distinctions, as well as from a statement by comparatist Owen Aldridge (108): "The purpose of comparative literature is to reveal differences as well as similarities." Perhaps a search for hidden differences, either in areas passed over because of the highly visible resemblances or emerging from those very resemblances, would reveal the dimly sensed merits of La Bicyclette bleue. Here is what I found. 
In the area of character portrayal, much has been made of Scarlett and Léa, heroines each caught up in a war she hates. But Scarlett, with her stubborn will to survive, with her solemn oath that neither she nor her folks will ever be hungry again (421), is supremely individual. Her reaction to hardship and danger is to show resource. She sees immediate situations and copes with them; author Mitchell underlines Scarlett's inability to deal in abstractions. Léa is more symbolic: in the drab repression of occupied France, she is like an unquenchable Rabelaisian life-force, devouring with equal gusto food, books and sex while running her dangerous errands for the French Resistance; she is freedom made flesh. Even the blue of her bicycle has connotations of liberty for the French. Léa faces privation with angry impatience, and peril with a kind of frightened courage. She is well informed and grasps the larger issues of which her adventures are a part. Equally memorable, these two protagonists are not the same.

They are especially unlike in the matter of sexuality. Making allowance for the difference in historical settings (1860s/1940s) and the different times of writing (1930s/1980s), one can still say that Scarlett's attitude to the libido is negative, Lea's positive. For Scarlett, sex means either frightening surrender of self, or entrapment through unwanted babies. For Léa it means pleasure, the freely chosen gratification of desire. These themes of desire ('J'ai envie de lui'»), pleasure ("Elle aimait avec un joyeux paganisme») and, linking the two, woman's freedom to initiate ("-Si nous faisions l'amour?») (all 1:326) combine to give the character of Léa a place in French feminist literature. In fact, both as author and as France's first woman publisher, Régine Deforges has had a long, costly battle with the authorities over what she calls eroticism and they consider obscenity. ${ }^{8}$ Sexual and political freedom are not unconnected; «Une littérature érotique est une littérature subversive," she told interviewer Jean Royer (200).

In the focus on Léa and Scarlett, critics have overlooked two characters from $\mathrm{La}$ Bicyclettebleue of more literary merit than Léa Delmas and having no equivalent in Gone With the Wind. One is the tragic figure of Léa's uncle, Adrien Delmas, a Dominican, who chooses resistance over obedience, losing his faith in the process. More especially, there is Raphaël Mahl, the self-hating Jewish collaborationist, homosexual and unfulfilled artist, capable of twisted courage and abject betrayals. Disgusted and her life endangered by him, Léa retains a perverse sympathy which sets this complex and unusual portrait beautifully in perspective. Commentators have dismissed Mahl as being merely a minor literary figure named Maurice Sachs transposed unadorned into a novel, and Deforges herself assured a journalist from Marie-Claire that every word of Mahl's in the book was actually uttered by Sachs (Laroche, 505), but she did herself less than justice. Borrowing from life has never been any guarantee of successful art; Régine Deforges has given Raphaël Mahl great artistic reality.

Though both novels present a time of war, a difference emerges in the use of historical materials. Gone With the Wind is a finely documented traditional historical 
novel. Mitchell has absorbed her extensive reading and distilled it 'finely' over her books so that it is everywhere present and nowhere obtrusive; the Civil War and its aftermath are a setting for the story of Scarlett.

Deforges was only ten when her War ended, hence is not drawing on memory any more than Mitchell. The semi-mocking list of names, i.e., sources, referred to earlier, indicates that she too has done a great deal of preparatory reading, but the way she transmits this information to the reader is deliberately unsubtle. Fictional Frenchwomen, gathered round a radio, listen to a two page extract from the real text of a broadcast on Radio Londres about the murder of Jews (2:316-318). A fictional Léa, sitting on the balustrade of the Tuileries, watches De Gaulle's triumphal parade up the Champs-Elysées, and the author stops to let the General tell it himself, in a full page extract from his memoirs (3: 258-259). In short, history itself becomes the topic at intervals, and is served up in large undigested slices to make La Bicyclette bleue a very good example of that hybrid called the docu-roman.

Second World War France is not Civil War Georgia. Those too intent on outward resemblance miss the much better comparison of Occupied France in La Bicyclette bleue and the Reconstructionist Georgia of Gone With the Wind, nearly half of Mitchell's narrative being postbellum. Military occupation puts great moral pressure on a local populace. It is a time of choosing, and both novels excel in the presentation of choice.

Mitchell's characters are what they are, and simply react. The less adaptable turn their backs on the Yankee occupant and all he represents, in order to live in the past. Some of the plantation aristocracy do this with a kind of proud deliberateness which I still call 'reacting' because it is largely unvoiced. The tougher-minded, including Scarlett, grapple with the new present. To two characters, Ashley Wilkes and Rhett Butler, the author does give a voice to articulate what is happening.

The options followed by Deforges' characters are more diverse and, in the French tradition, involve greater self-awareness. Variously, these French men and women choose to fight the German occupant or fight for him, to snub him or sleep with him, to be tortured without denouncing, to denounce without being asked. Deforges might almost be said to have gone Sartre and Camus one better, preserving the philosophic aspect of choice, as when Laurent d'Argilat sums up wartime behaviour as «le règne de l'absurde» (3:284), but adding a human factor. Thus Léa risks great danger out of moral indignation at what the Nazis are doing, but also from a personal need to live free of constraint. Luc Delmas collaborates out of a systematic French bourgeois dislike for 'communists' and their ilk, but also in the hope of protecting his family. Mathias, in joining the Waffen S.S., opts to throw in his lot with the purifying Master Race, but also acts from frustration at being shut out of Léa's life. Considered as a theme, the anguish and consequences of choosing are one of the strengths of La Bicyclette bleue; scholar Resa Dudovitz (181) singles out for special admiration Deforges" "attempt to understand the mechanisms of collaboration and betrayal."

During the Liberation, when Léa vehemently condemns a Parisian mob for 
behaving 'worse than the Germans,' someone nearby cautions: «C'est possible, mais ce n'est pas le moment de le dire.» With the author's hindsight, Léa is able to retort: «Vous verrez que ce ne sera jamais le moment» (3:312). Indeed, fifty years later, France - or rather her Establishment - is still afraid to know who did what during the War. Literally not a month goes by but an observer of France, within or without, deplores the absence of an official, highest level inquiry, one that would enable the French, if not to reach a consensus of feeling, at least to purge themselves of a poison. The 1987 trial of Klaus Barbie, the Nazi "butcher of Lyons," should have provided such a forum, but after many delays the French elements of the Barbie story were declared out of scope. So that one still finds, in 1990, British journalist Paul Webster reproaching the authorities "d'avoir maintenu enterrée la responsabilité de la nation française" (in Libération, 14 mai, 5; in 1991, L'Express fulminating because «la France n'a jamais sérieusement cherché à analyser ces vieilles hontes» (p. 70), in 1992, a witness on a T.V. documentary (sources, Touvier) stating bluntly: «On fait tout en France pour éviter le procès de la Collaboration,...»"

The high function of offering catharsis through the arts has been left to cinema and the novel, with La Bicyclette bleue, blunt and bestselling, an outstanding example. I believe that is the book's chief contribution, a literary one and not deriving from Gone With the Wind. Mitchell invited her reader to share a certain view of controversial but non-threatening past events. She had no need, as Deforges does, to demand indignantly that the reader face up to the very existence of past events.

To do this, Deforges has first to captivate her reader through narrative. Which brings us back to the anecdote that opens this article, and the matter of bestsellers. Both novels are by common consent wonderful stories. Gone With the Wind is one of half a dozen books in my life which truly correspond to the expression 'I couldn't put it down.' La Bicyclette bleue - "exciting, real, adventurous, human, stirring, and more," as reviewer Davida Brautman put it (644) - had the same effect on my wife.

But if a wonderful story sells many copies, then academic critics (not Brautman, for whom Deforges' novel is "an important work") are apt to label it "Popular Culture" and be very guarded in their admiration. In 1936, Malcolm Cowley wrote that Gone With the Wind, though trite and sentimental, "suggests the great novelists of the past" (20, my emphasis). In 1987, Jacques Laroche (508) presented La Bicyclette bleue as popular literature, "a rich adventure story that is not an insult to the reader's intelligence."

Just as there is a danger that the use of such categories might prevent us from paying due tribute to a book, so there is a risk that blatant resemblance might obscure independent merit. I have tried to show that $L a$ Bicyclette bleue, which enormously and consciously resembles Gone With the Wind, has considerable literary merit independently of its model. 


\section{Notes}

1 Our story has an epilogue. We were in France again six years later when Deforges published a sequel to La Bicyclette bleue. Noir Tango is not as gripping as the original trilogy; my wife spoke to me several times while she was reading it, to tell me so.

2 Once each is a mere bagatelle for devotees of Margaret Mitchell; the world, not just the United States, abounds in people whose lives have been seriously marked by her work. For Gone With the Wind as a social phenomenon, see Taylor in the list of sources.

${ }^{3}$ Large sales figures were again in view for the sequels to the two novels, Alexandra Ripley's Scarlett and Régine Deforges' Noir Tango. Scarlett was released world wide on September 25, 1991, with Belfond handling the French edition; at 11 a.m. Belfond's retail outlet had none of its 600 copies left to sell me.

An unrepentant Deforges brought out her sequel that same day. Ramsay publishers planned 260,000 copies for the first printing of Noir Tango, Belfond 150,000 for that of the French Scarlett $(V S D, 54)$.

${ }^{4}$ The Blue Bicycle (London: W.H. Allen, 1985 and New Jersey: Lyle Stuart, 1986).

5. There have since been two appeals. The first was by Ramsay and was successful: the appeal court ruled that $L a$ Bicyclette bleue was not «une contrefaçon littéraire» after all. (Libération, 22 nov. 1990, 29). That judgment in turn was quashed by the Cour de Cassation (Liberation, 5 fév. 1992, 48), and the final outcome is still pending.

6 The details of the California proceedings were obtained, via computer network, by W.K. Whiteway, Reference Librarian at the College of Law, University of Saskatchewan, to whom I am indebted.

7

Attending a panel discussion of authors and their translators in Paris, 1992, I was interested to hear participant Deforges take the same attitude to writing as Léa to sex. Where other panelists were being slightly pious when asked about the writer's responsibility, she simply said she writes for her pleasure.

8 Some idea of this battle may be had from a biographical sketch in Histoire de la litterature de langue française... (2: 987): Deforges «crée les éditions L'Or du temps en 1968 et publie une centaine d'ouvrages dont la plupart font l'objet d'interdictions diverses. Procès et amendes l'obligent à poser son bilan.»

9 An exhibition in March-April, 1992, came close. Le Sort des Juifs en France pendant la Guerre 
a) was held in and sponsored by City Hall, Paris and b) referred to «l'active complicité de certains de nos concitoyens.» These words were signed by Jacques Chirac, Paris mayor and former prime minister, giving them a kind of official cachet.

\section{Bibliography}

A.

Deforges, Régine. La Bicyclette bleue. Paris: Ramsay.

vol. 1 - La Bicyclette bleue, 1982.

vol. 2 - 101, Avenue Henri-Martin, 1983.

vol. 3 - Le Diable en rit encore, 1985.

Mitchell, Margaret. Gone With the Wind [1936]. New York: Avon, 1973.

B.

Aldridge, A. Owen. Comparative Literature: Matter and Method. Urbana, Ill.: U. of Illinois Press, 1960.

Brautman, Davida Beth. «Deforges, Régine. La Bicyclette bleue (3) [etc.].» French Review, vol. 59, No. 4, March, 1986.

Cowley, Malcolm. "Going with the Wind," book review in The New Republic, 1936. Reprinted in Darden Asbury Pyron, ed., Recasting: Gone with the Wind in American Culture. Miami: University Presses of Florida, 1983.

Dictionnaire des littératures de langue française, ed. J.-P. de Beaumarchais and others. Paris: Bordas, 1987.

Dimanche Magazine, Paris weekly. ?, 1985, pages magazines, 5.

Dudovitz, Resa Lynn. The Myth of Superwoman: A Comparative Study of Women's Bestsellers in France and the United States, 1987 Ph.D. dissertation of the University of Illinois at UrbanaChampaign. Ann Arbor, Michigan: University Microfilms International.

Express, L', Paris weekly. 27 avril-3 mai 1990. Article «Enquête sur un crime oublié,» by Eric Conan. A landmark piece of journalism with regard to Vichy and the Jews. 
Federal Supplement, Cases Argued and Determined in the United States District Courts [etc.]. St. Paul, Minn.: West Publishing Co., vol. 479, 1980.

Histoire de la littérature de langue française des années 1930 aux années 1980, ed. Pierre de Boisdeffre. Nouvelle édition. Paris: Perrin, 1985.

Laroche, Jacques M. «A Success Story in the French Popular Literature of the 1980s: La Bicyclette bleue.» French Review, vol. 60, No. 4, March 1987.

Libération, Paris daily. Dates as shown in text.

Monde, Le, Paris daily. 5 oct., 1989.

Printout (see note 6), law report labelled thus: 1988 WL 62755 (C.D. Cal.), 1988 Copr. L. Dec. P 26, 221, 5 U.S.P.Q. 2d1874, 14 Media L. Rep. 2340.

Royer, Jean. Ecrivains contemporains - Entretiens - 3, 1980-1983. Montréal: L'Hexagone, 1985.

Taylor, Helen. Scarlett's Women - Gone With the Wind and Its Female Fans. New Brunswick, N.J.: Rutgers University Press, 1989.

Touvier. «L'Affaire Touvier,» TV broadcast in the series Envoyé spécial. France: Channel A2, Feb. 27, 1992.

VSD, Paris weekly. 15 au 21 août, 1991. 